\title{
Stratification of patients with COPD according to the 2011 GOLD report
}

\author{
Stratyfikacja pacjentów z POChP według raportu GOLD 2011
}

The authors declare no financial disclosure

\section{Abstract}

Introduction: The authors aimed to compare the distribution of COPD based on the new GOLD grading with stadium based exclusively on spirometry.

Material and methods: Eligible patients had an average age of 64.8 years and smoked at least 10 pack-years. COPD was defined according to GOLD fixed cut-off criterion $\mathrm{FEV}_{1} / \mathrm{FVC}<0.70$. In all patients postbronchodilator spirometry was performed. Categories were defined with the mMRC dyspnoea scale and CAT scale. COPD exacerbations in the previous year and lung function were evaluated. Statistical comparisons were done using t-student test.

Results: 315 COPD patients, 99 (31.4\%) women and 216 (68.6\%) men, were examined. Mean pack-years in the whole group was $47.1 \pm 17.8$. In women this figure was less than in men, $43.7 \pm 19.2$ vs $49.5 \pm 16.5$ ( $p>0.05)$, respectively. At study entry, 144 subjects (45.7\%) were current smokers, and the majority of them ( $n-87,60.4 \%)$ belonged to category $D-26 / 66(54.5 \%)$ women and 51/102 (50\%) men. Based on spirometry alone, the patients were classified as moderate COPD $144(45.71 \%)$, severe - 154 (48.89\%), and very severe 17 (5.4\%). According to the 2011 GOLD report stratification, 60 patients (19.04\%) were graded as category $A, 63(20 \%)$ as category $B, 24(7.62 \%)$ as category $C$, and $168(53.33 \%)$ as category $D$, although $21(12.5 \%$ of them) were in category $B$, but the number of exacerbations classified them as category $D$.

Conclusions: The COPD population is heterogeneous in reference to the symptoms, value of $\mathrm{FEV}_{1}$, and susceptibility to exacerbations. Clinical symptoms assessed using validated questionnaires characterized COPD patients better than the value of spirometric parameters (which are necessary for diagnosis of this disease). Some patients were difficult to classify, especially those belonging to category $\mathrm{C}$.

Key words: category ABCD, CAT questionnaire, COPD, 2011 GOLD report, spirometry

Pneumonol. Alergol. Pol. 2014; 82: 415-421

\section{Streszczenie}

Wstęp: Celem pracy było porównanie rozkładu POChP według nowej gradacji GOLD ze stadium ocenianym wyłącznie na podstawie spirometrii.

Pacjenci i metody: Pacjenci spełniający warunki byli w wieku 64,8 roku i palili papierosy co najmniej 10 paczkolat. POChP było zdefiniowane według GOLD z wartością $\mathrm{FEV}_{1} / \mathrm{FVC}<0,70$ po teście odwracalności obturacji. Kategorie zostały określone według skali duszności mMRC i skali CAT. Oceniano zaostrzenia POChP w ciągu ostatniego roku i wskaźniki wentylacji. Opracowanie statystyczne wykonano przy użyciu testu $t$-studenta.

Wyniki: W badaniach analizowano 315 pacjentów z POChP: 99 (31,4\%) kobiet i 216 (68,6\%) mężczyzn. Palenie papierosów określone średnią wartością paczkolat w całej grupie wynosiło $47,1 \pm 17,8$, ale średnia paczkolat u kobiet była krótsza niż u mężczyzn, odpowiednio 43,7 $\pm 19,2$ vs 49,5 $\pm 16,5$ ( $p>0,05$ ). Przy przystępowaniu do badania 144 osoby $(45,7 \%)$ nadal pality papierosy, większość z nich (n-87 - 60,4\%) należała do kategorii D - 36/66 (54,5\%) kobiet i 51/102 (50\%) mężczyzn. Na podstawie tylko

Address for correapondence: Prof. Iwona Grzelewska-Rzymowska, MD, PhD, Department of Pneumonology and Allergology, Medical University of Lodz, ul. Kopcińskiego 22, 90-153 Łódź, tel. +48 42 6787505, fax: +48 4267821 29, e-mail: rzym@binar.pl

DOI: 10.5603/PiAP.2014.0054

Praca wpłyneła do Redakcji: 11.02.2014 r.

Copyright (C) 2014 PTChP

ISSN 0867-7077 
spirometrii POChP umiarkowaną sklasyfikowano u 144 pacjentów (45,71\%), ciężką u 154 (48,89\%), a bardzo ciężka u 17 (5,4\%). Według raportu GOLD 201160 pacjentów (19,04\%) zostało zakwalifikowanych do kategorii $A, 63$ (20\%) do kategorii $B, 24$ (7,62\%) do kategorii C i 168 (53,33\%) do kategorii D, chociaż 21 (12,5\%) z nich było w kategorii B, lecz liczba zaostrzeń spowodowała zakwalifikowanie ich do kategorii D.

Wnioski: Populacja z POChP jest heterogenna pod względem objawów, wartości FEV, i podatności na zaostrzenia. Objawy kliniczne oceniane przy użyciu zwalidowanych kwestionariuszy lepiej charakteryzują pacjentów z POChP niż wskaźniki spirometryczne, które są konieczne w diagnozowaniu tej choroby. Niektórych pacjentów trudno sklasyfikować, szczególnie tych do kategorii C.

Słowa kluczowe: kategorie A, B, C, D, kwestionariusz CAT, POChP, raport GOLD 2011, spirometria

Pneumonol. Alergol. Pol. 2014; 82: 415-421

\section{Introduction}

Chronic obstructive pulmonary disease (COPD) is one of the leading causes of morbidity and mortality worldwide, and it is expected to increase over the coming decades. In 1990 COPD was the sixth cause of death, and in 2030 it is estimated that it will become the fourth leading cause of death worldwide [1]. The cardinal symptoms of COPD are chronic and progressive dyspnoea, chronic cough, and sputum production in patients with a history of current or former cigarette smoking or exposure to other risk factors such as passive smoking and occupational agents [2]. In COPD-suspected patients, spirometry is required because this disease is characterised by persistent airflow limitation, which is confirmed by post-bronchodilator $\mathrm{FEV}_{1} / \mathrm{FVC}<0.70$ [2].

Morbidity from COPD may be affected by other comorbid chronic conditions, including cardiovascular disease, skeletal muscle dysfunction, metabolic syndrome, osteoporosis, depression, or lung cancer [3-5]. The comorbidities occur in patients with different stages of airflow limitation. Worsening airflow limitation is associated with the increasing prevalence of exacerbation and the risk of death [6]. A great number of clinical trials proved that the severity of airflow limitation described according to previous GOLD reports alone have not characterised COPD in individual patients because the level of $\mathrm{FEV}_{1}$ is an inadequate descriptor of the impact of COPD on a patient [6-8].

The 2011 GOLD consensus proposed a new approach to patients with COPD as well as COPD assessment, which enables the understanding of the impact of COPD on an individual patient [9]. The goal of combined personalised COPD assessments is to determine the severity of the disease, including the severity of airflow limitation, and to assess the symptoms of COPD using validated questionnaires that evaluate the degree of disability due to breathlessness and the impact of the disease on a patient's daily life and well-being. Recently, several multidimensional indices have been presented for prognostic purposes in COPD [10-12].

The aim of the study was to determine the distribution of the new groups as proposed by 2011 GOLD report category A, B, C, and D by using combined personalised COPD assessment and to compare it to previous categorisation of the same patients.

\section{Material and methods}

The study was performed on patients suffering from COPD, diagnosed at least two years before in an outpatient pulmonary clinic. The patients were enrolled from 1 February, 2011 to 8 April, 2012. COPD was defined by history of smoking more than 10 pack-years (defined as 20 cigarettes a day for 10 years or 10 cigarettes a day for 20 years), $\mathrm{FEV}_{1}$ (expiratory volume in one second) less than $80 \%$ of the predicted value, and post-bronchodilator $\mathrm{FEV}_{1} / \mathrm{FVC}$ (after bronchodilator use) less than 0.70. The patients' COPD before their enrolment to the study was clinically stable for at least six weeks before entry and they received optimal medical therapy according to the previous GOLD report [2]. All the participants gave their informed, written consent to participate in it and the study was approved by the Bioethics Committee of the Medical University of Łódź, Poland. All exams of individual patients were carried out on the same day.

In all patients, spirometry tests were performed at baseline and 15 minutes after the administration of 400 mcg of salbutamol in accordance with the American Thoracic Society (ATS)/ European Respiratory Society (ERS) consensus criteria of acceptability and reproducibility, using a volumetric storage spirometer (Vitalograph 2160, Vitalograph Ltd.) [13]. Airway limitation was stratified using ATS/ERS and GOLD report severity classification as follows: mild $\left(\mathrm{FEV}_{1} \%\right.$ 
$\geq 80)$, moderate $\left(\mathrm{FEV}_{1} \% 50-79\right)$, severe $\left(\mathrm{FEV}_{1} \%\right.$ $30-49)$, and very severe $\left(\mathrm{FEV}_{1} \%<30\right)[2,9,14]$.

Assessment of symptoms in our COPD patients was done using two validated questionnaires recommended by the 2011 GOLD report. Functional dyspnoea was evaluated by Modified British Medical Research Council (mMRC) dyspnoea index, which assesses only breathlessness (scale 0-4) [15]. The other was the COPD Assessment Test (CAT) (scale 0-40), which describes the patient's daily life and the impact of COPD on his/ her well-being. This questionnaire is more repeatable and less sensitive to change than mMRC [16]. A CAT score $\geq 10$ and $\mathrm{mMRC} \geq 2$ indicates a high level of symptoms $[17,18]$.

The annual exacerbation was calculated on the basis of an individual patient's history and medical documentation from the previous 12 months. An exacerbation of COPD was characterised by the definition given by Burge and Wędzicha [19]. According to this definition, COPD exacerbation is an acute event characterised by a worsening of the patient's respiratory symptoms that is beyond normal day-to-day variations and leads to the need for a change in medication. Only these exacerbations of COPD, which required hospitalisation or treatment with antibiotics and/or systemic corticosteroids, were taken into account. Patients with two or more exacerbations during the last year were considered to have frequent exacerbations.

In the study, 2011 GOLD report grading of the stage of COPD severity was used [9]. According to this new approach, four categories of COPD are proposed.

Category A: low risk, mild or moderate airway limitation GOLD1, GOLD2, fewer symptoms mMRC $<2$, CAT score $<10$ and/or $\leq 1$ exacerbation per year. Category B: low risk, more symptoms, GOLD1 or GOLD2 (mild and moderate airflow limitation), mMRC $\geq 2$, CAT score $\geq 10$, $\leq 1$ exacerbation per year. Category C: high risk, fewer symptoms, GOLD3 or GOLD4 (severe or very severe airflow limitation, mMRC $<2$, CAT score $<10, \geq 2$ exacerbations per year. Category D: high risk, more symptoms, GOLD3 or GOLD4, mMRC $\geq 2$, CAT score $\geq 10, \geq 2$ exacerbation per year. Assessment of exacerbation risk was calculated for individual patients.

\section{Statistical analysis}

Descriptive data are reported as mean \pm SD or percentage, as appropriate. Comparisons between groups were performed using $t$-student test. In all analysis, a value $<0.05$ was considered for statistical significance.

\section{Results}

The study included 99 (31.4\%) women and $216(68.6 \%)$ men with mean age of $64.8 \pm 7.0$ years. The women were younger than the men $(63.2 \pm 7.6$ vs. $66.5 \pm 6.4, p>0.05)$. Mean time of COPD duration in the whole group was 6.3 \pm 3.7 years (range: $2-20$ years) (Table 1 ). Mean pack-years in the whole group was $47.1 \pm 17.8$. The number of mean pack-years in women was less, at $43.7 \pm 19.2$ (range: $20-120$ ), than in men $-49.5 \pm 16.5$ (range: $25-90$ but not significantly $\mathrm{p}>0.05$ ) (Table 1).

At study entry 144 (45.7\%) subjects were current smokers, and the majority of them (n-87; $60.4 \%$ ) were category D 36/66 (54.5\%) women and $51 / 102(50.0 \%)$ men, current cigarettes smokers (that probably explains why the smokers were in category D); other patients gave up smoking mainly after experiencing a cardiovascular event. Based on spirometry alone, the patients from the group which we examined were classified based on $\mathrm{FEV}_{1}$ as moderate - 144 (45.71\%), severe - 154 (48.89\%), and very severe - 17 (5.4\%) (Table 2). According to the 2011 GOLD report stratification, 60 patients $(19.04 \%)$ were graded as category A (low risk, less symptoms),

\section{Table 1. Patient demographics and baseline characteristics}

\begin{tabular}{lc}
\hline Number of patients & 315 \\
Age at enrolment (yrs) & $64.8 \pm 7.0$ \\
(range) & $(50-81)$ \\
& \\
The time of COPD duration (yrs) & $6.3 \pm 3.7$ \\
(range) & $(2-20)$ \\
Pack years smoked & $47.1 \pm 17.8$ \\
(range) & $(20-120)$ \\
Current smokers & $144(45.7 \%)$ \\
$\mathrm{n}(\%)$ & \\
Female gender & \\
$\mathrm{n}(\%)$ & $99(31.4 \%)$ \\
age & $63.2 \pm 7.6^{*}$ \\
mean-pack-years & $43.7 \pm 19.2^{* *}$ \\
(range) & $(20.0-120)$ \\
Male gender & \\
$\mathrm{n}(\%)$ & $216(68.6 \%)$ \\
age & $66.5 \pm 6.4^{*}$ \\
mean-pack-years & \\
(range) & $(25.0-90.0)$ \\
Post bronchodilator $\mathrm{FEV}{ }_{1} \%$ pred. & \\
$<30, \mathrm{n}(\%)$ & $17(5.4)$ \\
$\geq 30<50, \mathrm{n}(\%)$ & $154(48.89)$ \\
$\geq 50, \mathrm{n}(\%)$ & $144(45.71)$ \\
\hline Data are presented as mean $\pm \mathrm{SD} ;{ }^{*} \mathrm{p}>0.05 ;{ }^{* *} \mathrm{p}>0.05$ \\
\end{tabular}


Table 2. Stratification of COPD patients based on the old groups and categories ABCD (GOLD 2011)

\begin{tabular}{lccccc}
\hline \multirow{2}{*}{$\begin{array}{l}\text { Old GOLD } \\
\text { group }\end{array}$} & A & \multicolumn{3}{c}{ Categories } & Total N (\%) \\
\cline { 2 - 5 } & 60 & B & C & D & \\
\hline II & - & - & - & 21 & $144(45.71)$ \\
III & - & - & 1 & 131 & $154(48.89)$ \\
IV & $60(19.04)$ & $63(20.0)$ & $24(7.62)$ & $168(53.3)$ & $315(100)$ \\
Total N (\%) & & & & & $16.4)$ \\
\hline
\end{tabular}

Table 3. Categories ABCD according 2011 GOLD Report

\begin{tabular}{|c|c|c|c|c|c|c|}
\hline & & A & B & C & D & \\
\hline Number of patients (\%) & & $60(19.05)$ & $63(20)$ & $24(7.62)$ & $168(53.33)$ & $315(100)$ \\
\hline Sex F/M & & $9 / 51$ & $24 / 39$ & $0 / 24$ & $66 / 102$ & $99 / 216$ \\
\hline $\begin{array}{l}\text { Age (yers) } \\
\text { (range) }\end{array}$ & & $\begin{array}{l}64.8 \pm 6.5 \\
(50-75)\end{array}$ & $\begin{array}{c}65.5 \pm 6.6 \\
(51-78)\end{array}$ & $\begin{array}{c}67.5 \pm 5.8 \\
(59-77)\end{array}$ & $\begin{array}{c}64.6 \pm 7.5 \\
(51-81)\end{array}$ & NS \\
\hline \multirow{2}{*}{$\begin{array}{l}\text { Duration of COPD in years } \\
\text { (mean } \pm \text { SD) }\end{array}$} & Female & 5.6 & 4.5 & - & 7.4 & \\
\hline & Male & 5.8 & 8.6 & 4.8 & 6.5 & \\
\hline $\begin{array}{l}\text { Pack-years } \\
\text { (range) }\end{array}$ & Female & $\begin{array}{l}39.4 \pm 7.8^{*} \\
\quad(27-46)\end{array}$ & $\begin{array}{c}38.6 \pm 5.0^{* *} \\
(31-45)\end{array}$ & - & $\begin{array}{c}46.5 \pm 22.9 * * * \\
(20-120)\end{array}$ & NS \\
\hline $\begin{array}{l}\text { Pack-years } \\
\text { (range) }\end{array}$ & Male & $\begin{array}{c}45.7 \pm 19.2^{*} \\
(26-90)\end{array}$ & $\begin{array}{c}45.1 \pm 13.6^{* *} \\
(25-70)\end{array}$ & $\begin{array}{l}49.1 \pm 7.7 \\
(45-74)\end{array}$ & $\begin{array}{c}55.5 \pm 17.3^{* * *} \\
(25-90)\end{array}$ & NS \\
\hline $\begin{array}{l}\mathrm{FEV}_{1} \text { mean \% pred value } \\
\text { (range) }\end{array}$ & & $\begin{array}{c}64.0 \\
(52.4-72)\end{array}$ & $\begin{array}{c}58.54 \\
(53-72)\end{array}$ & $\begin{array}{c}47.56 \\
(27-48.1)\end{array}$ & $\begin{array}{c}45.8 \\
(27.6-64)\end{array}$ & \\
\hline $\begin{array}{l}\text { CAT scores } \\
\text { (range) }\end{array}$ & & $\begin{array}{c}8.14 \\
(7-9)\end{array}$ & $\begin{array}{c}14.7 \\
(10-22)\end{array}$ & $\begin{array}{c}9.8 \\
(8-9)\end{array}$ & $\begin{array}{c}22.35 \\
(13-25)\end{array}$ & \\
\hline
\end{tabular}

Data are presented as mean \pm SD; Pack-years ${ }^{*} p>0.05 ;{ }^{* *} p>0.05 ;{ }^{* * *} p>0.05$

$63(20.0 \%)$ as category B (low risk, more symptoms), $24(7.62 \%)$ as category $\mathrm{C}$ (high risk, less symptoms), and 168 (53.33\%) as category D (high risk, more symptoms) (Table 3). Among them, 21 $(12.5 \%)$ subjects were classified as II old group; however, analysis of their mMRC and CAT scores classified them as category B, but the number of COPD exacerbations meant that they were stratified in category D.

According to the 2011 GOLD report, "if there is a discrepancy between the risk category as assessed by spirometric classification and that derived from exacerbation history, the assessment pointing to the highest risk should be used.' That explains why some patients with moderate COPD were stratified to category D.

\section{Discussion}

According to the 2001 GOLD consensus report and its update in 2006, the diagnosis, assessment of severity, and treatment of COPD were guided by the degree of airflow limitation that was not fully reversible. Thus, the GOLD reports recommended the staging of COPD severity on the basis of spirometry alone [2]. But some clinical trials established that COPD is a complex, heterogeneous disease with numerous pulmonary and extrapulmonary components [20, 21]. Finally, the ECLIPSE cohort proved that COPD is characterised by heterogeneity with respect to clinical presentation, physiology, imaging, response to therapy, decline in lung function, and survival [6]. $\mathrm{FEV}_{1}$ by itself failed to adequately describe the complexity of this disease. Recently, Casanova et al. [22] in a longitudinal study of a COPD cohort showed that the progression of COPD is highly heterogeneous, because most observed patients (73\%) had no decline in $\mathrm{FEV}_{1}$ characteristics for COPD. Based on clinical and functional variables, several validated, multidimensional indices have been offered for clinical practices. Among them is the BODE index (Body Mass Index, $\mathrm{FEV}_{1}$, Dyspnoea, and Exercise capacity) which has proven 
to be better than $\mathrm{FEV}_{1}$ at predicting the risk of death from respiratory and other causes, among COPD patients [10]. The other multidimensional indices are the $\mathrm{ADO}$ index (Age, Dyspnoea, $\mathrm{FEV}_{1}$ ) and DOSE index (Dyspnea, $\mathrm{FEV}_{1}$, Smoking status and Exacerbations) [11, 12].

The new GOLD consensus report update (as of 30 December, 2011) uses airflow limitation, history of COPD exacerbations, and symptoms to classify and grade the severity of the disease [9]. Based on this new approach to COPD, described as combined personalised assessment of COPD, our patients were stratified into categories ABCD. It refers to both men and women. Patients with severe and very severe COPD on the basis of $\mathrm{FEV}_{1}$, amounting to $168(53,3 \%)$ in total, were stratified to category D, but 24 (7.62\%) of them with accompanying severe decline in $\mathrm{FEV}_{1}$ appeared to have resistance to exacerbations and they were included in category C. Twenty-one $(12.5 \%)$ patients with moderate decline in $\mathrm{FEV}_{1}$ but with more symptoms of COPD were also stratified into category D instead category B because they experienced a lot of exacerbations of COPD. Thus, classification to category $\mathrm{D}$ in this group of patients was determined by the frequency of exacerbations and admission to hospital [9]. Analysis of the data from the COPD gene large patient cohort study also showed a small number of patients in category C (7.9\%) and the largest group of patients were stratified to category $\mathrm{D}$ (38\%) [23]. Thus, we assume that patients with a low value of $\mathrm{FEV}_{1}$ and low level of symptoms of COPD but with frequent exacerbation symptoms make up a small group of COPD patients. On the grounds of the study carried out by Hurst et al. [24], the frequency and severity of exacerbations which characterised the patients with 'frequent' and 'infrequent' exacerbations tended to remain in the same category. There are two proposed methods for assessing exacerbation risk. The first method is based on a patient's medical history of exacerbations. According to the 2011 GOLD report, two or more episodes of COPD exacerbations per year classifies him/her as a 'frequent exacerbator' [9]. From the definition these patients should be stratified to category C or D. But clinical study results show that exacerbations evoke more clinical symptoms of COPD, which are presented in higher CAT and mMRC scores [25]. Moreover, exacerbations have a significant negative influence on the clinical course of COPD [26, 27], which is why the patients with mild or moderate values of $\mathrm{FEV}_{1}$ should be stratified into category D instead of category C. In our study used this method since we were in possession of all the data from the patients' medical histories. The second method relies on $\mathrm{FEV}_{1}$. When this parameter is below $50 \%$ of the predicted value, which is characterised by a great number of exacerbations and a few symptoms, the patient is stratified into category $\mathrm{C}$. The number of exacerbations can be calculated from the 2011 GOLD report [9] based on the ECLIPSE, TORCH, and UPLIFT studies [6-8]. However, a history of previous exacerbations is the best predictor of future exacerbation risk in all stages of COPD severity [24]. The COPD exacerbations imply a worse prognosis [26-28].

While analysing the frequency of COPD exacerbations we should keep in mind that patients often do not report exacerbations to health care professionals [27]. Exacerbations of COPD and, especially, any hospital admissions are associated with a poor prognosis [28, 29]. It is well documented that COPD exacerbations are serious events because they usually have an infectious origin and are associated with inflammation of the respiratory system and with systemic inflammation [30]. Thus, J. Wędzicha [31] postulates that patients with frequent exacerbations but mild or moderate symptoms should fall into one category regardless of $\mathrm{FEV}_{1}$ decline. She also concludes that a simpler version of categorisation is necessary. Categories A and B should include patients with mild and moderate symptoms represented by CAT scores, and then a broader higher-risk exacerbation group should be combined with frequent exacerbators, especially patients with hospital admissions [31]. Han et al. [23], while analysing a COPD gene cohort and considering the 2011 GOLD report, stated that where exacerbation risk, as defined by $\mathrm{FEV}_{1}$ or previous exacerbation history, is not identical, further classification to category C or D should be used. In their stratification patients in $\mathrm{C} 1$ and $\mathrm{D} 1$ categories met $\mathrm{FEV}_{1}$ criteria, $\mathrm{C} 2$ and $\mathrm{D} 2$ met exacerbation criteria only, and C3 and D3 met both $\mathrm{FEV}_{1}$ and exacerbation criteria. This stratification of COPD patients is reasonable but complicated in clinical practice. That is why in our study we only used the simpler stratification into category $C$ and $D$, but we suggest that a simpler version with one group of patients with frequent exacerbation is better. The 2013 GOLD report propagates that for classification of patients, the clinical COPD questionnaire (CCQ) is a reliable, short and easy, self-administered, validated questionnaire. 0-1 points in the CCQ is considered for patients from categories $\mathrm{A}$ and $\mathrm{C}$, and $\geq 1$ point is for patients from categories B and D [32]. 
The mean time of duration of COPD was 6.3 years. Short duration of COPD results only from late diagnosis of the disease, which took place in a specialist clinic but not in primary care. Even in patients with severe decline in $\mathrm{FEV}_{1}(\leq 50 \%$ of the predicted value), their COPD was diagnosed in a short time. It must be stressed that COPD is a disease that takes a long time to diagnose when the inflammatory process is already responsible for big changes in the respiratory system as well as in extrapulmonary organs [30]. COPD is an under-diagnosed disease because it is usually not detected until patients seek medical attention for dyspnoea or an exacerbation.

Multiple COPD characteristics are termed COPD phenotypes. They classify patients into distinct subgroups that provide prognostic information and allow improvement of current clinical practice. Han et al. [33] characterised a phenotype of COPD as a single attribute or combination of disease attributes that describe the differences between patients with COPD. These attributes refer to symptoms, exacerbations, response to therapy, rate of disease progression, or death [24, 33, 34]. Other phenotypes have been proposed, for example a fast decliner with a greater than average fall in $\mathrm{FEV}_{1}$, and inflammatory phenotype with elevated serum concentration of inflammatory markers [35, 36]. A different phenotype is presented by current smokers, but this phenotype is in all other phenotypes. The special phenotype is the overlap COPD - asthma. This mixed phenotype is diagnosed in 13\% of COPD patients with a history of asthma before the age of 40 years [37].

Tobacco smoking is the main risk factor of COPD and it is also the main determinant of poor outcome in subjects who suffer from COPD $[38,39]$. De Marco et al. [39] showed that COPD may start early in life and that smoking is the main risk factor for COPD. The other strong risk factors are airway hyperresponsiveness, respiratory infections in childhood, and a family history of asthma. It is believed that COPD occurs after 20 to 25 pack-years of exposure. De Marco et al. [40] showed that in their cohort about half of the incident cases of COPD had smoked for less than 20 pack-years. Thus, there is a hypothesis that COPD does not reflect only the cumulative exposure to cigarette smoke, but also early interaction of tobacco smoking with some genetic or immunological host characteristics [41].

In the studied group, the average time of smoking was 47.1 years. But in all categories, female groups were lower (but not significantly) than male groups (Table 3). We cannot establish whether 20 pack-years is enough for developing advanced stadium of COPD as we diagnosed our patients already in this stadium. Over $45 \%$ of the patients we studied were current smokers, but they were more prevalent in high-risk group D $(51.7 \%)$. This data is contrary to the results presented by Han et al. [23], who found that current smoking was less prevalent in this category of patients: $50 \%$ in category A vs. $10 \%$ and $28 \%$ in categories C3 and D3, respectively. We assume that current smoking among patients in group $\mathrm{D}$ is responsible for frequent exacerbations and decline in $\mathrm{FEV}_{1}$. These differences in our and Han's outcomes in reference to current smoking probably result from cultural habits and poorer levels of education of our patients.

In summary, we have demonstrated that the COPD population is heterogeneous with regard to the symptoms, value of $\mathrm{FEV}_{1}$, and susceptibility to exacerbations. Over half of the patients were in category $\mathrm{D}$, which is characterised by frequent exacerbations, and over $51 \%$ of them were current smokers. The identification of this group of patients is very important from a clinical point of view because COPD exacerbations can be prevented by numerous methods, thus reducing acute events. First, intensive smoking cessation strategies must be adopted in these patients. Moreover, influenza and pneumococcal vaccination should be offered to all COPD patients together with treatment with long-acting inhaled bronchodilators and $\backslash$ or long acting anticholinergic agents, with or without inhaled corticosteroids and a phosphodiesterase inhibitor. Triple inhaled therapy is also recommended [9].

\section{Conflict of interest}

The authors declare no conflict of interest.

\section{References:}

1. Mathers C.D., Loncar D. Projections of global mortality and burden of disease from 2002 to 2030. PloS Med. 2006; 3: e442.

2. Rabe K.F., Hurd S., Anzueto A. et al. and the Global Initiative for Chronic Obstructive Lung Disease. Global strategy for the diagnosis, management, and prevention of chronic obstructive pulmonary disease: GOLD executive summary. Am. J. Respir. Crit. Care Med. 2007; 176: 532-555.

3. Soriano J.B., Visick G.T., Muellerova H. et al. Patterns of comorbidities in newly diagnosed COPD and asthma in primary care. Chest 2005; 128: 2099-2107.

4. Mannino D.M., Thorn D., Swensen A., Holguin F. Prevalence and outcomes of diabetes, hypertension and cardiovascular disease in COPD. Eur. Respir. J. 2008; 32: 962-969.

5. Curkendall S.M., Lanes S., de Luise C. et al. Chronic obstructive pulmonary disease severity and cardiovascular outcomes. Eur. J. Epidemiol. 2006; 21: 803-813. 
6. Agusti A., Calverley P.M., Celli B. et al. and the Evaluation of COPD Longitudinally to Identify Predictive Surrogate Endpoints (ECLIPSE) investigators. Characterisation of COPD heterogeneity in the ECLIPSE cohort. Respir. Res. 2010; 11: 122-136.

7. Calverley P.M., Anderson J.A., Celli B. et al. TORCH investigators. Salmeterol and fluticasone propionate and survival in chronic obstructive pulmonary disease. N. Engl. J. Med. 2007; 356: 775-789.

8. Tashkin D.P., Celli B., Senn S. et al. Uplift Study Investigators. A 4-year trial of tiotropium in chronic obstructive pulmonary disease. N. Engl. J. Med. 2008; 359: 1543-1554.

9. Vestbo J., Hurd S.S., Agusti A.G. et al. Global Strategy for Diagnosis, Management, and Prevention of Chronic Obstructive Pulmonary Disease. GOLD Executive Summary. Am. J. Respir. Crit. Care Med. 2013; 187: 347-365.

10. Celli B.R., Cote C.G., Marin J.M. et al. The body-mass index, airflow obstruction, dyspnea, and exercise capacity index in chronic obstructive pulmonary disease. N. Engl. J. Med. 2004; 350: 1005-1012.

11. Puhan M.A., Garcia-Aymerich J., Frey M. et al. Expansion of the prognostic assessment of patients with chronic obstructive pulmonary disease: the updated BODE index and the ADO index. Lancet 2009; 374: 704-711.

12. Jones R.C., Donaldson G.C., Chavannes N.H. et al. Derivation and validation of a composite index of severity in Chronic Obstructive Pulmonary Disease The DOSE Index. Am. J. Respir. Crit. Care Med. 2009; 180: 1189-1195.

13. Miller M.R., Hankinson J., Brusasco V. et al. ATS/ERS Task Force. Standardisation of spirometry . Eur. Respir. J. 2005; 26: 319-338.

14. Celli B.R., MacNee W., and committee members. Standards for the diagnosis and treatment of patients with COPD: a summary of the ATS/ERS position paper. Eur. Respir. J. 2004; 23: 932-946.

15. Bestall J.C., Paul E.A., Garrod R., Garnham R., Jones P.W. Wedzicha J.A. Usefulness of the Medical Research Council (MRC) dyspnoea scale as a measure of disability in patients with chronic obstructive pulmonary disease. Thorax 1999; 54: 581-586.

16. Jones P.W., Harding G., Berry P., Wiklund I., Chen W.H., Leidy N.K. Development and first validation of the COPD Assessment Test. Eur. Respir. J. 2009; 34: 648-654.

17. Jones P.W., Harding G., Wiklund I. et al. Tests of the responsiveness of the Chronic Obstructive Pulmonary Disease (COPD) Assessment Test TM (CAT) following acute exacerbation and pulmonary rehabilitation. Chest 2012; 142: 134-140.

18. Jones P.W., Brusselle G., Dal Negro R.W. et al. Properties of the COPD assessment test in a cross-sectional European study. Eur. Respir. J. 2011; 38: 29-35.

19. Burge S., Wędzicha J.A. COPD exacerbations, definitions and classifications. Eur. Respir. J. 2003; 21 (suppl. 41): 46-53.

20. Soriano J.B., Alfageme I., Almagro P. et al. Distribution and Prognostic Validity of the New Global Initiative for Chronic Obstructive Lung Disease Grading Classification. Chest 2013; 143: 694-702.

21. Agusti A. COPD, a multicomponent disease: implication for management. Respir. Med. 2005; 99: 670-682.

22. Casanova C., de Torres J.P., Aguirre-Jaime A. et al. The progression of chronic obstructive pulmonary disease is heterogenous. The experience of the BODE cohort. Am. J. Respir. Crit. Care Med. 2011; 184: 1015-1021.

23. Han M.K., Muellerova H., Curran-Everett D. et al. GOLD 2011 disease severity classification in the COPD Gene study: a pro- spective cohort study. Lancet Respir. Med. 2012; Special Preview August 2012: 15-22.

24. Hurst J.R., Vestbo J., Anzueto A. et al. and the Evaluation of COPD Longitudinally to Identify Predictive Surrogate Endpoints (ECLIPSE) Investigators. Susceptibility to exacerbation in chronic obstructive pulmonary disease. N. Engl. J. Med. 2010; 363: 1128-1138.

25. Mackay A.J., Donaldson G.C., Patel A.R., Jones P.W., Hurst J.R., Wedzicha J.A. Usefulness of the chronic obstructive pulmonary disease assessment test to evaluate severity of COPD exacerbations. Am. J. Respir. Crit. Care Med. 2012; 185: 1218-1224.

26. Wedzicha J.A., Seemungal T.A.R. COPD exacerbations: defining their cause and prevention. Lancet 2007; 370: 786-796.

27. Seemungal T.A.R., Donaldson G.C., Paul E.A., Bestall J.C., Jeffries D.J., Wedzicha J.A. Effect of exacerbation on quality of life in patients with chronic obstructive pulmonary disease. Am. J. Respir. Crit. Care Med. 1998; 157: 1418-1422.

28. Soler-Cataluña J.J., Martinez-Garcia M.A., Roman Sanchez P., Salcedo E., Navarro M., Ochando R. Severe acute exacerbations and mortalilty in patients with chronic obstructive pulmonary disease. Thorax 2005; 60: 925-931.

29. Suissa S., Dell'Aniello S., Ernst P. Long-term natural history of COPD: severe exacerbations and mortality. Thorax 2012; 67: 957-963.

30. Fabbri L.M., Rabe K.F. From COPD to chronic systemic inflammatory syndrome? Lancet 2007; 370: 797e9.

31. Wedzicha J.A. GOLD and ABCD - a good start, but now for the evidence? Lancet Respir. Med. 2012; August Special Preview: $2-3$.

32. Han M.K., Agusti A., Calverley P.M. et al. Chronic obstructive pulmonary disease phenotypes. The future of COPD. Am. J. Respir. Crit. Care Med. 2010; 182: 598-604.

33. Global Strategy for the Diagnosis, Management and Prevention of COPD, Global Initiative for Chronic Obstructive Lung Disease (GOLD) 2013. Available from: www.goldcopd.org.

34. Soler Cataluna J.J., Martinez-Garcia M.A., Catalan Serra P. The frequent exacerbator. A new phenotype in COPD? Hot Topics Respir. Med. 2011; 19: 7-12.

35. Vestbo J., Edwards L.D., Scanlon P.D. et al. Changes in forced expiratory volume in 1 second over time in COPD. N. Engl. J. Med. 2011; 365: 1184-1192.

36. Agusti A., Edwards L.D., Rennard S.I. et al. Persistent systemic inflammation is associated with poor clinical outcomes in COPD a novel phenotype. PLoS One 2012; 7: e37483.

37. Hardin M., Silverman E.K., Barr R.G. et al. The clinical features of the overlap between COPD and asthma. Respir. Res. 2011; 12: 127.

38. Anthonisen N.R., Skeans M.A., Wise R.A., Manfreda J., Kanner R.E., Connett J.E. Lung Health Study Research Group. The effects of a smoking cessation intervention on 14.5-year mortality: a randomized clinical trial. Ann. Intern. Med. 2005; 142: $233 \mathrm{e} 9$.

39. de Marco R., Accordini S., Marcon A. et al. Risk factors for chronic obstructive pulmonary disease in a european cohort of young adults. Am. J. Respir. Crit. Care Med. 2011; 183: 891-897.

40. de Marco R., Accordini S., Marcon A., i wsp. Incidence of chronic obstructive pulmonary disease in a cohort of young adults according to the presence of chronic cough and phlegm. Am. J. Respir. Crit. Care Med. 2007; 175: 32-39.

41. Cosio M.G., Saetta M., Agusti A. Immunologic aspects of chronic obstructive pulmonary disease. N. Engl. J. Med. 2009; 360: $2445-2454$. 